\title{
The Belt and Road Initiative: The Cornerstone of the New-Fangled Financial Institutionalism Led by China
}

\author{
Enrique Martínez Galán \\ ISEG-Lisbon School of Economics and Management, \\ University of Lisbon \\ Asian Development Bank \\ 6 ADB Avenue, 1550 , \\ Mandaluyong City, Metro Manila, the Philippines \\ E-mail: egalan@adb.org \\ Francisco José Leandro \\ Institute for Research on Portuguese Speaking Countries, \\ City University of Macau \\ Avenida Xian Xing Hai 105, \\ Centro Golden Dragon, Room G512A, \\ Macau SAR, People's Republic of China \\ E-mail: franciscoleandro@cityu.mo
}

Abstract: The debate about the benefits and the risks brought both to People's Republic of China and to the other participant countries by the Belt and Road Initiative (BRI) has been gaining momentum in the academic and in the political landscapes. We argue that the BRI is the main pillar of the new financial institutionalism proposed by China to redefine the current global financial architecture and that, consequently, the initiative needs to be considered in that context. This paper (i) reviews the timeline that led to this Chinese-led new financial institutionalism, (ii) proposes two theoretical frameworks to define the concept of multilateral financial statecraft and of new financial institutionalism led by China, and (iii) enumerates the main differences and similarities observed between this new financial institutionalism and the one dominated by the Bretton Woods-related institutions that gradually emerged after World War II, such as the International Bank for Reconstruction and Development, the Marshall Plan, and the Asian Development Bank.

Keywords: Asian Infrastructure Investment Bank, Belt and Road Initiative, China, development finance, economic diplomacy, financial institutionalism, 
financial statecraft, international financial institutions, multilateral development banks

\section{Introduction}

The current global financial architecture has been dominated by the international financial institutions that were created during the Bretton Woods conference in 1944. The World Bank and the International Monetary Fund (IMF), jointly with the several regional development banks that emerged since then, namely the Inter-American Development Bank (IADB) in 1959, the African Development Bank (AfDB) in 1964, the Asian Development Bank (ADB) in 1966, and the European Bank for Reconstruction and Development (EBRD) in 1990, have been setting the rules of the global financial game. The distribution of voting power in the two original institutions continue to largely reflect today the geopolitical and economic weight that emerged from World War II. The leading role attributed to the United States (US) and to Western Europe has been preserved. The regional development bank created in the 1960s emerged as a first attempt by developing members to have a greater say in the global financial architecture. Borrowing shareholders, defined as those countries eligible to borrow from the World Bank's International Development Association (IDA) or International Bank for Reconstruction and Development (IBRD), own the majority of the voting power in all these three institutions, namely 59.2\% in the AfDB (AfDB, 2018 ); $52.3 \%$ in the ADB (ADB, 2018); and 50.1\% in the IADB (IADB, 2018). However, the US managed to keep enough capital in the IADB to veto $(30.7 \%)$ and in the ADB to strongly influence (15.6\%) key decisions. The US also keeps a sizeable position in the AfDB and in the EBRD (EBRD, 2018). Table 1 shows a comparison between voting power in MDBs and economic weight.

Emerging and developing countries gradually increased their relative weight in the world economy, from $16.5 \%$ in 1993 to 38\% in 2017, as shown in Table 2. In that same period, China's weight alone increased from $1.7 \%$ to $15.2 \%$. Nevertheless, the Chinese increasing relative weight in the world's economy had no reflection in their relative voting power in international financial institutions. In 2009 , the Chinese economy represented $8.5 \%$ of the world's GDP, but just $2.8 \%$ of the IBRD's voting power. The demands made by several emerging and developing economies led to the World Bank Group voice reform approved by its Governors in April 2010 (The World Bank, 2010). 
Table 1. Voting power distribution in major international financial institutions (\% of total voting power in a given institution), as per 31 December 2017

\begin{tabular}{|c|c|c|c|c|c|c|c|}
\hline \multirow{3}{*}{ Shareholder } & \multicolumn{7}{|c|}{ Voting Power } \\
\hline & \multicolumn{2}{|c|}{ IBRD } & \multirow{2}{*}{ IMF } & \multirow{2}{*}{ ADB } & \multirow{2}{*}{ AfDB } & \multirow{2}{*}{ IADB } & \multirow{2}{*}{ EBRD } \\
\hline & (2010) & (2017) & & & & & \\
\hline US & 16.4 & 16.0 & 16.5 & 12.8 & 6.6 & 30.0 & 10.1 \\
\hline Japan & 7.9 & 6.9 & 6.2 & 12.8 & 5.5 & 5.0 & 8.6 \\
\hline $\begin{array}{c}\text { Big Four European } \\
\text { countries }\end{array}$ & 15.9 & 14.3 & 16.4 & 9.6 & 12.1 & 6.7 & 34.4 \\
\hline China & 2.8 & 4.5 & 6.1 & 5.4 & 1.2 & 0.004 & 0.1 \\
\hline $\begin{array}{c}\text { IDA \& IBRD borrowing } \\
\text { members }\end{array}$ & 37.1 & 39.3 & n.a. & 39.1 & 59.2 & 50.02 & 14.4 \\
\hline
\end{tabular}

Sources: The World Bank, 2010; 2018a; IMF, 2018; IADB, 2018; ADB, 2018; AfDB, 2018; EBRD, 2018. Big Four European countries include France, Germany, Italy, and the United Kingdom. The World Bank (2015) lists the IDA \& IBRD borrowing countries.

Table 2. Relative weight in world's Gross Domestic Product measured in current US dollars (\%, 1993-2017)

\begin{tabular}{|c|c|c|c|c|c|c|c|}
\hline Shareholder & $\mathbf{1 9 9 3}$ & $\mathbf{1 9 9 7}$ & $\mathbf{2 0 0 1}$ & $\mathbf{2 0 0 5}$ & $\mathbf{2 0 0 9}$ & $\mathbf{2 0 1 3}$ & $\mathbf{2 0 1 7}$ \\
\hline US & 26.6 & 27.4 & 31.8 & 27.6 & 24.0 & 21.7 & 24.0 \\
\hline Japan & 17.2 & 14.0 & 12.9 & 10.0 & 8.7 & 6.7 & 6.0 \\
\hline $\begin{array}{c}\text { Big Four } \\
\text { European Countries }\end{array}$ & 21.4 & 20.6 & 18.3 & 19.9 & 17.8 & 14.8 & 13.4 \\
\hline China & $\mathbf{1 . 7}$ & $\mathbf{3 . 1}$ & $\mathbf{4 . 0}$ & $\mathbf{4 . 8}$ & $\mathbf{8 . 5}$ & $\mathbf{1 2 . 5}$ & $\mathbf{1 5 . 2}$ \\
\hline $\begin{array}{c}\text { IDA \& IBRD } \\
\text { Borrowing Members }\end{array}$ & 16.5 & 19.2 & 18.9 & 21.6 & 29.2 & 37.0 & 38.0 \\
\hline
\end{tabular}

Source: World Bank, 2017. Big Four European countries include France, Germany, Italy, and the United Kingdom. The World Bank (2015) lists the IDA \& IBRD borrowing countries.

The aftermath of the 2007-2011 economic and financial crisis, which showed the fragilities of major high-income economies, opened a new opportunity for emerging and developing economies to demand a bigger say in international financial institutions, although with limited success. Despite its growing economic and financial clout, China opted not to initially take a leading role in the debate. China followed first a soft and more pragmatic approach focusing on progressively gaining a presence in regional development banks. China progressively became a shareholder of the World Bank (and of the IMF) in 1980, 
the AfDB in 1985, the ADB in 1986, the IADB in 2009 and, more recently, of the EBRD in 2016. In all cases, the primary goal was to offer Chinese firms the possibility to become eligible for the procurement (public works, goods and equipment, and engineering and consulting services) of those institutions.

However, China seems now to be pursuing a different strategy that challenges the status quo and might even systemically transform the global financial multilateral architecture, based on the following pillars:

1. Step-by-step internationalization of the renminbi;

2. The Chiang Mai Initiative Multilateralization, increasingly seen as the "Asian IMF";

3. The Contingent Reserve Arrangement, or the "BRICS IMF";

4. The recently re-named New Development Bank (NDB), or BRICS Bank;

5. The Asian Infrastructure Investment Bank (AIIB); and

6. The Belt and Road Initiative (BRI).

We will focus in this paper on the last three of these pillars, which are those related to project finance for infrastructure, and, particularly, on the BRI. This will allow us to review the strategy followed by the Chinese government of exporting beyond its frontiers the domestic financial statecraft model that has been feeding its economic development in recent decades. By internationalizing the activity of Chinese agents, this new strategy not only increases demand for Chinese goods and contractors, mitigating the risk of a slow landing of the growth rates of the Chinese economy both in the short and in the medium run, but it also creates a Chinese-led new financial institutionalism that emerges as an alternative to the current global financial institutionalism, led by the US, which was inaugurated by the Bretton Woods institutions. Section 2 reviews the steps that China took to build an alternative to the current US-led global financial institutionalism and proposes a theoretical framework for the concept of multilateral financial statecraft. Section 3 defines the four pillars of the new financial institutionalism proposed by China. Section 4 discusses the role played by the BRI in this new financial institutionalism. Section 5 enumerates the main differences and similarities observed between the Chinese-led global financial institutionalism and the one dominated by the Bretton Woods-related institutions that gradually emerged after World War II. Section 6 concludes. 


\section{How China got to know the global financial institutionalism that emerged from and after Bretton Woods: a theoretical framework}

The role played by China in the international financial institutions that emerged from and after the Bretton Woods conference could be divided in three periods: (i) the inward-looking period; (ii) the learning curve; and the (iii) period of increasing demands.

The inward-looking period started in 1944 and continued until 1980. In that period, China, defined as the People's Republic of China for the purpose of this paper, had no contacts with international financial institutions. In 1980, the Chinese Government based in Beijing took over from the Government based in Taipei the representation of China at both the World Bank and the IMF.

The learning curve of China with the international financial institutions started immediately, right in 1980. While the Republic of China had been one of the founder members of both Bretton Woods institutions back in 1945, they have never borrowed from the World Bank. The first loan (of the IBRD) to China was approved only in 1981, one year after the recognition of Beijing as the representative of China in the institution (see Economy \& Oksenberg, 1999, for further details). Since then, the World Bank Group lending to China increased significantly, as shown in Table 3. Internal data obtained from the World Bank shows that annual lending committed to China increased, first, from 400 million US dollars in 1981 to an all-time record of 6.8 billion US dollars in 1994 and, again, from a relative low figure of 1.2 billion US dollars in 2001 to 4.5 billion US dollars in 2017. In addition, internal data obtained from ADB shows a very gradual and stable increasing pattern to a peak of 2.7 billion US dollars in 2017 and a relative weight in total ADB lending consistently ranging between $15 \%$ and $20 \%$. Total cumulative lending committed by both institutions in 31 December 2018 amounted 163.3 million US dollars (126.7 billion US dollars, in 537 projects, by the World Bank and 40.6 million US dollars by ADB).

After the World Bank and IMF, China became shareholder of the AfDB in 1985. The motivation for China to join the AfDB was not borrowing, but granting access for Chinese contractors, goods, equipment and consultants to procurement contracts financed by the Bank. After the World Bank, IMF and AfDB, China also joined the ADB in 1986 (both for borrowing and procurement purposes), the IADB in 2009 (for procurement), and the EBRD in 2016 (also for procurement). Table 4 shows the amounts obtained by Chinese contractors in the World Bank, ADB, AfDB and IADB from 2012 to 2017, cumulatively 
amounting 30.8 billion US dollars. China was in that period the most successful country in procurement in those banks, representing $19.2 \%$ of the procurement of these institutions in volume, followed by India with $12.8 \%$.

Table 3. Chinese borrowing from the World Bank and from the Asian Development Bank (committed amounts in current billion US dollars, 1981-2018)

\begin{tabular}{|c|c|c|c|c|c|c|c|c|}
\cline { 2 - 9 } & \multicolumn{7}{c|}{ Annual average } & Total \\
\cline { 2 - 9 } & $\begin{array}{c}1981- \\
1986\end{array}$ & $\begin{array}{c}1987- \\
\mathbf{1 9 9 2}\end{array}$ & $\begin{array}{c}\mathbf{1 9 9 3 -} \\
\mathbf{1 9 9 8}\end{array}$ & $\begin{array}{c}\mathbf{1 9 9 9 -} \\
\mathbf{2 0 0 4}\end{array}$ & $\begin{array}{c}\mathbf{2 0 0 5 -} \\
\mathbf{2 0 1 0}\end{array}$ & $\begin{array}{c}\mathbf{2 0 1 1 -} \\
\mathbf{2 0 1 6}\end{array}$ & $\begin{array}{c}\mathbf{2 0 1 7 -} \\
\mathbf{2 0 1 8}\end{array}$ & $\begin{array}{c}\mathbf{1 9 8 1 -} \\
\mathbf{2 0 1 8}\end{array}$ \\
\hline $\begin{array}{c}\text { World Bank } \\
\text { Group }\end{array}$ & 1.4 & 3.3 & 5.7 & 2.5 & 3.4 & 3.4 & 3.9 & 126.7 \\
\hline ADB & - & 0.3 & 1.0 & 1.1 & 1.6 & 1.9 & 2.4 & 40.6 \\
\hline Total & 1.4 & 3.6 & 6.7 & 3.6 & 5.0 & 5.3 & 6.3 & 167.3 \\
\hline
\end{tabular}

Source: Internal data obtained by the author from the World Bank and from the ADB.

Table 4. Absolute and relative weight of Chinese contractors and consultants in the procurement of the main Multilateral Development Banks (MDBs) (2012-2017)

\begin{tabular}{|c|c|c|}
\cline { 2 - 3 } \multicolumn{1}{c|}{} & $\begin{array}{c}\text { Absolute weight } \\
\text { (billion US dollars) }\end{array}$ & $\begin{array}{c}\text { Relative weight } \\
\text { (\% of total procurement) }\end{array}$ \\
\hline The World Bank & 15.4 & 19.3 \\
\hline ADB & 11.6 & 28.5 \\
\hline AfDB & 3.1 & 21.5 \\
\hline IADB & 0.7 & 2.7 \\
\hline Total & 30.8 & 19.2 \\
\hline
\end{tabular}

Source: Internal data obtained by the authors from the MDBs referred.

The first signs of a change in the Chinese approach to MDBs occurred in 2004, when China voluntarily ${ }^{1}$ contributed for the first time to a concessional window, namely to the ninth replenishment of the Asian Development Fund

China had already contributed to the African Development Fund (AfDF), the concessional window of the AfDB, when the country had become a member of the Bank. According to Article 3 of the Agreement Establishing the AfDB (AfDB, 2011), non-regional members of the bank need to contribute, on a compulsory basis, to the replenishments of its concessional window. This legal requirement applies retroactively, so when China became a shareholder of the AfDB in 1985, it not only had to contribute to the fourth replenishment of the AfDF, but also retroactively to the three previous replenishments (AfDF-I, AfDF-II and AfDF-III). 
(ADF-IX), with a small but emblematic contribution of 30 million US dollars (ADB, 2004). It was the additional learning step taken by China to add the role of donor to the two initial two roles of borrower and business promotor. This role was strengthened in 2008, not only with China's contribution to the tenth replenishment of the ADF, amounting 35 million US dollars (ADB, 2008), but particularly with China's first contribution to the fifteenth replenishment of the concessional window of the World Bank, IDA (IDA-15), with 30 million US dollars (The World Bank, 2008). In 2011, China increased its contribution to IDA-16 to 50 million US dollars and made a voluntary early repayment of its own IDA credits of 1 billion US dollars (The World Bank, 2011).

Having consolidated its activities as borrower, business promotor and donor, China continued demanding a more diversified and relevant role in MDBs by broadening its role to a fourth area: co-financier, based on the very significant presence of Chinese state-owned banks overseas. Dyer and Anderlini (2011) noted that the China Development Bank and the Export-Import Bank of China had jointly lent 110 billion US dollars to developing countries in 2009 and 2010 combined. This amount was already higher than the lending approved by the World Bank Group in the same period, despite of both banks being relatively recent (created in 1994). But the co-existence of the Chinese state-owned banks and the MDBs is not just one of competition. In May 2007, the Export-Import Bank of China and the World Bank signed a Memorandum of Understanding to collaborate and co-finance investment projects in Africa (The World Bank, 2007). This same instrument was replicated by the Export-Import Bank of China in 2012 with the IADB (IADB, 2012). China had, in fact, enlarged its presence in MDBs to the IADB in 2009. In this membership, although the shares available for subscription represented just $0.004 \%$ of the Bank's voting power (due to the opposition of the US to increasing IADB's authorized capital for this purpose), the People's Bank of China signed in 2013 a massive 2 billion US dollars' contribution to a brand new trust fund set by the IADB for cofinancing investment projects in Latin America and the Caribbean (IADB, 2013), strengthening its role as co-financier in MDBs. One year later, another contribution of 2 billion US dollars was announced for co-financing with the AfDB in Africa under the name Africa Growing Together Fund (AfDB, 2014).

Having a financially stronger and more diversified role in MDBs, the next step was logically demanding higher voice and representation in the governance and in the decision-making of the MDBs. The discussion about higher voice for developing and emerging economies had been initiated in the Spring Meeting of the World Bank in 2003, in response to the conclusions of the 2002 United Nations International Conference on Financing for Development held in 
Monterrey, Mexico. In April 2003, the World Bank's Development Committee "urged the Bank and the Fund to consider steps that might be taken to enhance the voice and effective participation of developing and transition countries in the work and decision-making of both Institutions" (The World Bank, 2003). The topic became a regular item in the final communiques of the meetings of the Development Committee that followed. However, the final decision was only taken seven years later, in the 2010 Spring meetings (World Bank, 2010). After all capital subscriptions materialized, the shareholding realignment agreed increased China's voting power from $2.8 \%$ to $4.4 \%$, an increase of 1.6 percentage points, the highest of all shareholders. Table 5 shows the main realignments observed. More recently, the agreement reached for a 2018 IBRD General Capital Increase would represent, when materialized, a further increase in the voting power of China, to 5.7\% (The World Bank, 2018b). In the case of the ADB, the discussion for higher voice and representation never started, prevented by the strong control exerted both by Japan and the US, much higher in a 67 -member than in a 189 -member bank, by definition.

Table 5. Main realignments observed in the shareholding of IBRD members after the implementation of the 2010 voice reform (percentage points)

\begin{tabular}{|c|c|}
\hline $\begin{array}{c}\text { Countries with the highest increase } \\
\text { in voting power (from higher to } \\
\text { lower) }\end{array}$ & $\begin{array}{c}\text { Countries with the highest decrease } \\
\text { in voting power (from higher to } \\
\text { lower) }\end{array}$ \\
\hline China (1.64) & Japan $(-1.01)$ \\
\hline South Korea $(0.58)$ & France $(-0.55)$ \\
\hline Turkey $(0.55)$ & United Kingdom $(-0.55)$ \\
\hline Mexico $(0.50)$ & US $(-0.51)$ \\
\hline Singapore $(0.24)$ & Germany $(-0.48)$ \\
\hline
\end{tabular}

Source: The World Bank, 2010

However, the relatively narrow realignment of shares observed under the World Bank's voice reform (China, with $4.4 \%$ of the voting power, became the third largest shareholder of the IBRD, but far from the voting power of the US, 15.9\%, and even Japan, 6.8\%; see The World Bank, 2010) and the maintenance of the status quo in the $\mathrm{ADB}^{2}$ forced China in 2013 to take another step in its relationship with MDBs. And a ground-breaking one: from demanding

2 Examples of countries barred from ADB membership are several (e.g., Brazil, Iran, Kuwait, Russia), for many reasons, but all of them having in common the opposition of US and Japan, despite a gentlemen's agreement informally agreed in the G-20 that, in time, all G-20 members should be shareholders of all major MDBs. 
shareholder (fifth stage) to leader (sixth). China moved forward with the setting of two new MDBs: first, a more efficient MDB aiming to finance infrastructure for the sake of promoting connectivity and economic development in Asia, and, second, jointly with Brazil, India, Russia, and South Africa, a MDB to finance domestic infrastructure in these five countries.

Table 6 proposes a theoretical framework that enumerates the six stages for a country to build a multilateral financial statecraft: from borrower to business promotor, then donor, co-financier, demanding shareholder and, finally, leader. These are sequential but, at the same time, co-existent.

Table 6. Stages of a multilateral financial statecraft

\begin{tabular}{|c|c|c|c|c|c|}
\hline Borrower & $\begin{array}{l}\text { Business } \\
\text { promotor }\end{array}$ & Donor & $\begin{array}{c}\text { Co- } \\
\text { financier }\end{array}$ & $\begin{array}{c}\text { Demanding } \\
\text { share- } \\
\text { holder }\end{array}$ & Leader \\
\hline $\begin{array}{c}\text { Joining } \\
\text { current } \\
\text { MDBs with } \\
\text { the purpose } \\
\text { of (gradually } \\
\text { increasing) } \\
\text { borrowing } \\
\text { domesti- } \\
\text { cally }\end{array}$ & $\begin{array}{l}\text { Joining } \\
\text { MDBs with } \\
\text { the purpose } \\
\text { of promoting } \\
\text { business } \\
\text { opportunities } \\
\text { for domestic } \\
\text { firms abroad }\end{array}$ & $\begin{array}{l}\text { Joining } \\
\text { on- } \\
\text { cessional } \\
\text { windows } \\
\text { of MDBs } \\
\text { as contri- } \\
\text { butor }\end{array}$ & $\begin{array}{c}\text { Using } \\
\text { domestic } \\
\text { financiers to } \\
\text { co-finance } \\
\text { project } \\
\text { infra- } \\
\text { structure } \\
\text { abroad }\end{array}$ & $\begin{array}{c}\text { Seeking } \\
\text { greater } \\
\text { voice and } \\
\text { repre- } \\
\text { sentation } \\
\text { in the } \\
\text { governance } \\
\text { of existing } \\
\text { multilateral } \\
\text { institutions }\end{array}$ & $\begin{array}{c}\text { Build } \\
\text { regional (and } \\
\text { eventually } \\
\text { global) } \\
\text { financial } \\
\text { institutions, } \\
\text { taking a } \\
\text { hegemonic } \\
\text { position } \\
\text { or dis- } \\
\text { proportionate } \\
\text { influence in } \\
\text { them }\end{array}$ \\
\hline
\end{tabular}

Source: Authors, inspired by Armijo \& Katada, 2014

The BRI emerges in this theoretical framework simultaneously covering the six stages. First, it increases borrowing domestically. Second, the BRI promotes the internationalization of Chinese firms abroad. Hillman (2018) found that $89 \%$ of all contractors participating in Chinese-funded transportation projects between 2006 and 2017 were Chinese firms, 8\% were local companies; and $3 \%$ were from third countries. Third, the BRI offers concessional assistance overseas: although around three-quarters of the Chinese lending overseas is offered on commercial, non-concessional, terms (normally ranging from $6 \%$ to $7 \%$ ), one quarter is offered in concessional terms, with interest rates of sovereign long-term lending by Chinese state-owned banks ranging from 
$1 \%$ to $3 \%^{3}$. Fourth, the BRI allows domestic financiers to finance project infrastructure abroad: Deloitte (2018) estimated that the Big Four state-owned banks, namely the Industrial and Commercial Bank of China, Bank of China, China Construction Bank, and Agricultural Bank of China, were responsible for $51 \%$ of total BRI financing by December 2016 in terms of outstanding loans and equity investment. In addition, the China Development Bank and the Export-Import Bank of China accounted for $38 \%$ and $8 \%$, respectively. In total, these six institutions provided $97 \%$ of the financing of the BRI. Fifth, the initiative gives China a greater voice and representation overseas. Sixth, the BRI puts China in a hegemonic position, with disproportionate influence. The European Commission, through its European Political Strategy Centre (EPSC), emphasised that "Chinese actions are not restricted to the economic and financial spheres; they seem to have a clear geopolitical and geostrategic component. The plethora of initiatives that are ostensibly economic-AIIB, NDB, the Silk Road - are clearly aimed, and overtly used, to increase global influence and political reach." (EPSC, 2015)

Historically, only three countries have fully followed, to different degrees, this chronology until the final stage, namely the United States (the Marshall Plan, Bretton Woods institutions and IADB), to some extent Japan (ADB), and, more recently, China (AIIB). The Big Four European countries, India, and Russia could be considered as very advanced in these stages, being sizable founding members of regional financial institutions (the EBRD and the NDB). However, none of them took a hegemonic position or disproportionate influence in those institutions. ${ }^{4}$

\section{The Chinese-led new financial institutionalism}

The new financial institutionalism proposed by China is a multi-pillar strategical umbrella that conglomerates national and multilateral financial institutions to promote Chinese domestic and foreign interests overseas. The participating states have scrutinized their own interests and chosen to participate in the financial mechanisms that, in their view, best protect and promote their national interests, acknowledging the inevitability of interdependence.

3 See Sirimanna, 2011, Government of Timor-Leste, 2015, and Zhang \& Miller, 2017, for further details and examples.

4 We do not consider for this exercise sub-regional development or investment banks, such as the Nordic Investment Bank, or the Eurasian Development Bank. 
We argue that China is promoting a new global financial institutionalism involving four types of intertwined mechanisms: (i) the creation of new multilateral financial institutions; (ii) extended multilateralism; (iii) bilateral initiatives; and (iv) partnerships.

First, China created and takes a leading role in two new multilateral quasi-global financial organizations, namely the AIIB and the NDB. We will elaborate on the role played by the AIIB in the new financial institutionalism proposed by China in the next section. In addition, apart from some sub-regional MDBs (China is a shareholder of the Caribbean Development Bank, but not of the Eurasian Development Bank or of the Development Bank of Latin America), China is a shareholder of all major multilateral banks.

Second, regarding extended multilateralism, China has been recently increasing its participation in global systemic organizations. China became a member of the World Trade Organization in 2011. In 2016, the renminbi was included in the IMF's Special Drawing Rights currency basket. In addition, China had established, by the end of 2017, fifteen official renminbi clearing centres worldwide, according to SWIFT (2018). ${ }^{5}$ In 2018, China initiated the importation of oil from Iran, Venezuela, Russia and Saudi Arabia, using the renminbi. Third, regarding bilateral initiatives, China has developed a network of Domestic Development Banks (DDB), quite active overseas in emerging and developing economies. EPSC (2015) observes that these banks have a joint capital base of over 100 billion US dollars and that "along with funds originating from the MDBs, they are also used to finance external infrastructures by supporting the investments of Chinese companies abroad". The China Banking Regulatory Commission (2016) noticed that, by the end of June 2015, 11 Chinese banks had established 15 subsidiaries, 31 branches, 8 representative offices, and 1 joint venture bank in 23 BRI countries. The Chinese banks, mainly the four state-owned commercial banks (Industrial and Commercial Bank of China, Agricultural Bank of China, China Construction Bank, and Bank of China), and the three policy-oriented development banks (China Development Bank, Agricultural Development Bank of China and Export-Import Bank of China) act as a "conglomerate of financial interests", guided by the central government's objective and supporting the same cooperation model shaped by the priorities of the BRI geo-economy.

Fourth, China is using partnerships to foster cooperative investment joint ventures.

5 Namely in Australia, Canada, France, Germany, Hong Kong, Luxemburg, Macao, Russia, Singapore, South Korea, Switzerland, Taiwan, United Kingdom, United Arab Emirates, and the US. 
This type of financial institutionalism is particularly interesting bearing in mind that it represents an evolution from bilateral relations and outside the realm of multilateral relations, but also an adjustment of relations with third powers. Partnerships are not static, and they do not have a single model as they are the result of ad hoc bilateral diplomatic will. They are built in common international projects, operationalized through a financial joint venture, and directed to a set of integrated infrastructures. The partnership financial dimension displays an important diplomatic function, as asserted by Nadkarni (2010, p. 46). Strüver (2017) defines "partnership diplomacy", for the specific case of China, as the "diplomatic instrument that allows for hedging against all eventualities while allowing for the common pursuit of mutual interests". Alternatively, Heath (2016) referred to China's approach as "neighbourhood diplomacy". In fact, China's neighbourhood is strategic for its diplomacy. In a key address to the Central Conference on Work related to Foreign Affairs, held in Beijing on 28-29 November 2014, President Xi, when presenting the BRI and the AIIB, referred to the need for China to

turn its neighbourhood areas into a community destiny, continue to follow the principles of amity, sincerity, mutual benefit and inclusiveness in conducting neighbourhood diplomacy, promote friendship and partnership with our neighbours, foster an amicable, secure and prosperous neighbourhood environment, and boost winwin cooperation and connectivity with our neighbours (Swaine, 2015).

The BRI emerges as the corollary of these partnerships. It is also a critical of China's neighbourhood diplomacy.

Finally, following the principle that the sum of the parts is more than the parts of the sum, it is worth noting that these four pillars will not only increase (i) the financing available for infrastructure and development in the Asia-Pacific region (also in renminbi); (ii) Chinese influence overseas; and (iii) business for (mostly) Chinese contractors, but these four intertwined mechanisms will in addition intensify the "chains of (financial) interdependence", as referred by Laroche (2017, p. 46). The fourth dimension, the partnerships, reinforces and is simultaneously reinforced by the other three dimensions, solving specific contextual challenges within the BRI. We will elaborate on the role played by the BRI in the new financial institutionalism proposed by China in the next section. 


\section{The role of the Belt and Road Initiative in the new financial institutionalism led by China}

In September 2013, President Xi proposed the launching of the Silk Road Economic Belt during an official visit to Kazakhstan. One month later, he complemented the Belt with a proposal to create the 21st-Century Maritime Silk Road (the Road) during an official visit to Indonesia for a meeting of Heads of State and Government of the Association of Southeast Asian Nations (ASEAN). In this same meeting, President $\mathrm{Xi}$ also announced China's intention to set a new MDB led by China, later named Asian Infrastructure Investment Bank (AIIB). All three announcements were made in one month's time.

First, regarding the BRI, the "project of the century", as President Xi named it, is a colossal infrastructural, intergenerational, multilevel and multidimensional access strategy to promote connectivity between economic agents and to bring about the next level of global prosperity. It is fundamentally a network of major infrastructures carefully collocated, providing different platforms for regional integration and interregional connectivity. The State and its institutions are at the centre of the "new economic cooperation model", where they perform different economic roles. The rationale for the BRI rests on a network of elements of connectivity that includes domestic development axes, economic corridors, fast transit routes and special economic zones or similar arrangements, along with land, maritime and immaterial dimensions (see Martínez-Galán, 2019, for a more detailed discussion about the boundaries of the initiative). All of these are trade integration initiatives that rely on infrastructure as a precondition for access to markets and production centres. This paper therefore inquiries into the extent to which the creation of a new financial institutionalism supports the setting of an extended network of infrastructural elements of connectivity.

Second, regarding the new MDB proposed by China, the AIIB, its aim was two-folded: "(i) promoting economic development and regional integration in Asia; and (ii) showing to the world that China was capable of leading a new MDB with the highest international practices in matters of governance, safeguard policies including environmental protection, resettlement, and debt sustainability, among others". ${ }^{6}$ The latest was an implicit message for the two most relevant MDBs operating in the Asian continent, which had shown little willingness to give China greater voice and representation, namely the World

6 Referred in an internal document with Frequently Asked Questions prepared by AIIB's Multilateral Interim Secretariat in charge of leading the negotiations of the Bank's Articles of Agreement (non-public). 
Bank and the ADB. China claimed that a better MDB was possible, particularly in efficiency and speediness. Regarding efficiency, AIIB implemented universal staff recruitment and procurement policies, meaning that the Bank can hire staff and firms regardless of their nationality, while the ADB limits recruitment and procurement to the nationalities of its 68 shareholders. Consequently, AIIB hires staff and firms from a wider pool, so, in principle, the likelihood of having the best staff or the best firm for the job is higher. As per 1 November 2018, 21 out of 178 AIIB staff were nationals from non-AIIB member countries, including 8 US nationals (AIIB internal document). For example, AIIB's first Legal Counsel was Natalie Lichtenstein, former Assistant General Counsel of the World Bank, and US national. Regarding speediness, Beijing aimed at having an MDB that is faster in delivering than the other Banks operating in the region of Asia and the Pacific, repeatedly described as too slow by beneficiary countries. According to internal assessments of those two banks, they take on average two years to prepare a given project from its concept note to Board approval, plus nine months from Board approval to the first disbursement. However, China needs now to make proof that, when operative, the AIIB will commit to transparency, efficiency, best practices, and that the Bank will deliver real value for their clients. AIIB will take some time to become fully operational and, at least in the beginning, it will not be easy for AIIB to compete with almost 50 years of ADB's experience with projects and clients and with ADB's vast network of resident missions in the 40 borrowing members, providing crucial support with technical assistance and capacity development to national country systems.

Finally, one year and a half before the proposal to create the AIIB, in March 2012, India had proposed during the fourth BRICS summit held in New Delhi, the creation of a new MDB for the five BRICS members. The agreement for its creation was reached in March 2013 during the fifth BRICS summit held in Durban. Both institutions, the AIIB and the NDB, started their activities in January 2016. Their creation revealed Beijing's willingness to employ its national financial capacities to set institutions and initiatives of global governance that might challenge the processes, institutions and norms of post-World War II global financial system.

Since Deng Xiaoping's leadership, economic sovereignty has been a driving force of Chinese foreign affairs. All the initiatives (BRI, DDBs, AIIB, NDB) are part of a larger package of measures put in motion by agents of economic diplomacy. Woolcock and Bayne (2013, p. 308) observed that "economic diplomacy $[\ldots]$ is about reconciling domestic and international policy objectives in an increasingly interdependent if not global economy [...] domestic policy objectives cannot be achieved independently of what is happening in the global 
economy or of the policies of other countries". Chinese economic sovereignty appears to be grounded on three intertwined pillars: (1) the promotion of human capital by breaching the gap between the littoral and the remote provinces and between different generations of Chinese workers; (2) the construction of physical infrastructure and technology production, with a rationale of domestic regional integration connected to overseas economic corridors; (3) and a set of political measures delivered by the political system as a whole. These three pillars require financing at a national, regional, interregional and perhaps global scale. Financing is central to advancing human capital, to constructing physical infrastructure and to producing advanced technology. Armijo and Katada (2015) define in this regard "financial statecraft" as "the intentional use, by national governments, of domestic or international monetary or financial capabilities for the purpose of achieving foreign policy goals, whether political, economic or financial". We claim that these financial capabilities are being served by a broad network of Chinese, Chinese-led or Chinese-influenced financial institutions, both bilateral and multilateral, that constitute a new financial institutionalism.

The BRI relies on infrastructural access and connectivity and, therefore, the financial institutional structure that supports the initiative requires two critical elements. The first is financial security and the second concerns attractive conditions to induce voluntary participation of other sovereign states. Financial security depends on the promotion of financial networks to rebalance the current state-of-affairs and the existing global financial institutions. Sovereign participation rests on national scrutiny vis-à-vis other sovereign units, assuming that interdependence is unavoidable.

This new financial institutionalism aims at becoming global. First, as of 5 September 2019, out of the 138 countries that have signed Memorandums of Understanding in support of the BRI with the Chinese government, ${ }^{7}$ more than half (85) are outside the Asia-Pacific region: 39 in Africa, 27 in Europe, and 19 in America (see Fig. 1). Second, NDB shareholders originate from three continents. Third, as per January 2019, out of the 100 members and prospective members of the AIIB, 50 were non-regional members (AIIB, 2019). Both AIIB's purpose (AIIB, 2015, Art. 1) and its allocation of voting powers (75\% to regional members and $25 \%$ to non-regional members) shows the Bank's regional nature, while also anticipating its relevance on an interregional scale: "we are the AIIB, a MDB with a mission to improve social and economic outcomes in Asia and beyond" (AIIB, 2018). In fact, the AIIB finances infrastructure projects outside Asia if they contribute for the connectivity of the continent (a vague concept).

7 This memorandum constitutes the basic notion of belonging to the BRI. 
As an example, the Bank approved in September 2017 the financing of eleven greenfield solar power plants in Egypt (AIIB, 2017).

Figure 1. BRI member countries (in dark gray), as per 5 September 2019

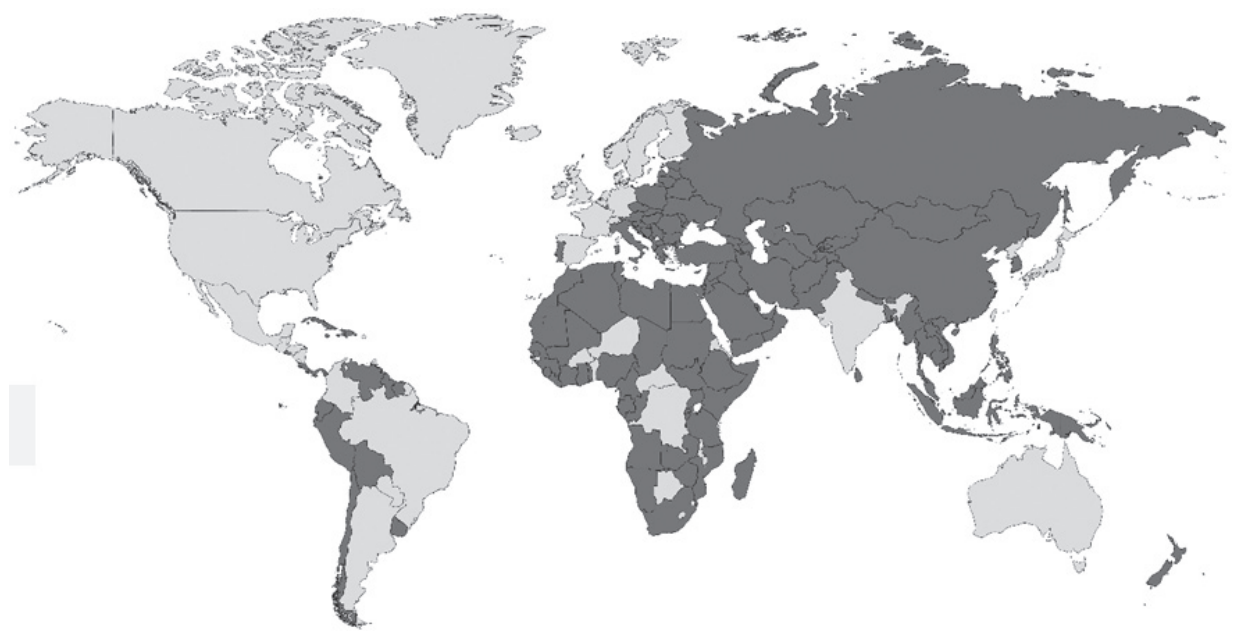

Source: Government of China, 2019

All in all, the impact of the BRI is also global, and significant. Zhai (2018) estimate the preliminary quantitative impact of the BRI for the next 15 years, using a global general equilibrium model and making just a moderate assumption of BRI investment, as (i) annual global welfare gains of 1.6 trillion US dollars in 2030, accounting for $1.3 \%$ of the global GDP; (ii) more than $90 \%$ of this gain expected to be captured by BRI countries, and (iii) global trade boost of $5 \%$ in 2030. In addition, the World Bank (2018c) estimates that it currently takes about 30 days to ship goods from China to Central Europe, with most goods being transported by sea, and that shipping goods by train can cut transit time in half. BRI's potential impact in reducing time transportation is meaningful. Ruta et al. (2018) estimate that the average decrease in shipping time caused by the BRI ranges between $1.2 \%$ and $2.5 \%$ across country pairs in the world and that the BRI reduces aggregate trade costs between $1.1 \%$ and $2.2 \%$ for the world. As for shipping times, the gains in trade costs vary widely across pairs of countries, with East Asia and Pacific as well as South Asia being the regions with the largest average reductions. For the BRI economies, the change in trade costs will range between $1.5 \%$ and $2.8 \%$. Djankov et al. (2006) also estimate that one-day delay in getting an item from the factory to the consumer reduces trade by $1 \%$. Shen and Chan (2018) argue nonetheless that it is still too early to draw conclusions about the impact of the BRI. 
Regardless of its impact, these three initiatives (BRI, AIIB, NDB) demonstrate an acceptance of the Chinese regional vision of cooperation based on connectivity access. The goal of playing a relevant role in the regional and even interregional financial architecture seems to be a major objective in China's new global financial institutionalism, despite the absence of certain countries such as Japan, Mexico, and the US. However, the isolationism advocated by the US and Japan, which not only refused participating in either the AIIB or the BRI, but actively lobbied their geo-strategical allies not to join them as well, had little success. The US' harsh but sterile complaints about the first request of AIIB membership made by a Western and also by a G-7 country, namely the United Kingdom, in 12 March 2015, less than three weeks before the deadline for founding membership request, were symptomatic (see Dyer \& Parker, 2015). In fact, seventeen other Western countries requested the status of prospective founding member in AIIB before the deadline of 31 March 2015.

Both the BRI and the AIIB share the same overarching pillars of open participation, non-interference, extensive consultation, joint contribution and shared benefits. Chhibber argued that

The AIIB, the Silk Road Fund, the NDB and the US\$100 billion Contingent Reserve Arrangement represent Chinese-backed new financial institutions that are not part of the existing Western dominated financial architecture. They will adhere to the Paris declaration but will not abide by the conditionality driven Development Assistance Committee (OECD DAC) framework. They are designed to help address issues of infrastructure underfunding, to create new pathways to sustainable development, south-south cooperation and mutually compatible solutions to development problems. (Chibber, 2017)

Ikenberry and Lim further argued that the

AIIB [helps] illuminate the logic of institutional creation as a strategic choice and tool of statecraft, including its opportunities, limitations, and likely impacts. Institutional statecraft may in some ways reinforce China's integration into, and stakeholder role and position in, the international system, while in others it may present various sorts of challenges to the existing system of rules and institutions. (Ikenberry \& Lim, 2017)

In terms of demand, infrastructure needs in Asia are vast. ADB (2017) estimates that developing Asia alone will require 26 trillion US dollars in infrastructure investment between 2016 and 2030 to maintain its growth momentum, eradicate 
poverty, and respond to climate change. This amount is equivalent to nearly 1.7 trillion US dollars annually. In addition, one should also bear in mind that this amount is estimated for the ADB's definition of Developing Asia, meaning that countries such as Russia, developed Asian countries, Middle Eastern countries and Turkey are not included in these figures. The financing needs are enormous, and the institutions and initiatives that serve the new financial institutionalism proposed by China can play a significant role in helping to meet them. Chinese banks held more than 22.6 billion US dollars in deposits in 2016 (Statista, 2018) and foreign exchange reserves in China exceeded 3.1 trillion US dollars in August 2018, nearly 9\% of the world's total (Trading Economics, 2018). The AIIB and the NDB have 100 billion US dollars of authorized capital each. Individually, the capital of each one of these institutions equals two-thirds of the capital of the ADB and about half that of the World Bank. The financing available for the BRI is estimated at 1 trillion US dollars, including the 40 billion financial endowment of the Silk Road Fund. ${ }^{8}$ Liquidity is therefore rapidly available for this new financial institutionalism.

The Chinese initiative aims at matching the needs of the BRI participating countries, the financing available by Chinese financial actors and the capacity to implement projects by Chinese constructors. The main actors implementing the BRI are, in fact, Chinese state-owned banks on one hand and Chinese stateowned enterprises on the other hand (referred to as "the SOE mobilization" in the context of the BRI by He, 2019). Regarding the Banks, the world's four largest banks by assets are Chinese, namely, in the following order, the Industrial and Commercial Bank of China, the China Construction Bank, the Agricultural Bank of China, and the Bank of China, totalling 13.5 trillion US dollars in assets according to Standard \& Poor's (2018). The same source includes 18 Chinese banks in the world's top 100. In addition, Chinese banks enjoy low borrowing costs, because their bonds are treated like virtual sovereign debt by the markets ${ }^{9}$ and they have access to direct lending from the People's Bank of China. Regarding the firms, Hillman (2018) mentions that the number of Chinese firms included in Fortune's Global 500 list of the world's largest companies by revenue increased from ten in 2000 (nine state-owned) to 120 firms as of July 2018 (81 state-owned). This increasing trend was especially

8 The Silk Road Fund provides investment and financing support, mainly equity, for the BRI. The Fund has a financial endowment of 40 million US dollars and 100 billion renminbi. Its shareholders are the State Administration of Foreign Exchange (65\%), China Investment Corporation (15\%), Export-Import Bank of China (15\%), and China Development Bank (5\%) (Silk Road Fund, 2018).

9 China's sovereign credit rating is A+ according to Standard \& Poor's and Fitch and A1 according to Moody's. 
evident in the construction industry. In 2017, seven of the world's ten largest construction firms, by revenue, were Chinese.

The relationship between the traditional MDBs and the BRI is very diversified. While the BRI is, according to the Chinese government, open to the voluntary participation of all countries and all institutions worldwide, three major global and regional powerhouses, the US, Japan, and Australia, have been actively advocating, both bilaterally and multilaterally, for the isolationism of the initiative, as it was also the case (unsuccessfully) of the US and Japan in the negotiations for the creation of the AIIB back in 2015. Several bilateral initiatives have been proposed in recent years to counteract the influence exerted by the BRI. First, the 110 billion US dollar Partnership for Quality Infrastructure proposed by Japan in 2015, financed by the ADB together with the Japanese International Cooperation Agency, the Japanese Bank for International Cooperation and the Japanese Overseas Infrastructure International Corporation (see Ministry of Foreign Affairs, 2015). Second, the creation of a 60 billion US dollar new finance development agency acting in Asia by the US (see Chandran, 2018). Third, the Strategy for Connecting Asia and Europe presented in September 2018 by the European Commission and the Council of the European Union (EU) (European Union, 2018), significantly increasing financial resources for infrastructure connecting the two continents in the EU 2021-2027 Multiannual Financial Framework. Finally, the creation of a 2.2 billion US dollar Pacific Infrastructure Fund by Australia announced in November 2018 (Packham, 2018). Second, in multilateral terms, the US-Japan-Australia dominated institution, ADB, has been very reluctant to any coordination with the BRI. While the other relevant MDBs operating in Asia, the World Bank and the EBRD have dedicated section in their websites dedicated to the BRI, ${ }^{10}$ the website of the ADB, the largest MDB in the region by approvals, makes no reference to the BRI at all. In response to the claims made that the projects financed under the BRI has several potentially negative effects in the borrowing members, such as increasing indebtedness, environmental and social fragilities, transparency and the lack of local labour force in the projects (see Martínez-Galán, 2019, for further details), China has been promoting initiatives that could mitigate those effects by attracting MDBs to the projects. Remarkably, the Chinese Finance Ministry signed a 'Memorandum of Understanding on collaboration on matters of common interest under the BRI' on 14 May 2017 at the margin of the Belt and Road Forum in May 2017 with six MDBs (ADB, AIIB, EBRD, NDB, European Investment

10 https://www.worldbank.org/en/topic/regional-integration/brief/belt-and-road-initiative and https://www.ebrd.com/what-we-do/belt-and-road/overview.html, respectively. 
Bank, and the World Bank) (see Ministry of Finance, 2017). In that document, the seven stakeholders committed to collaborate in: (a) enhancing support to infrastructure and connectivity projects; (b) building stable, diversified, and sustainable development financing mechanisms; (c) strengthening coordination and capacity building; and (d) supporting the implementation of the United Nations 2030 Agenda for Sustainable Development, the Achievement of the Sustainable Development Goals, and the Paris Agreement on Climate Change (Ministry of Finance, 2017, Art 1).

In its Article 3, China refers "its commitment to establish the Multilateral Cooperation Center for Development Finance (MCCDF) to promote concrete actions and cooperation in the five areas above and will invite collaboration with MDBs" (Ministry of Finance, 2017, Art. 3). In this regard, China internally distributed to those MDBs in the second half of 2018 a concept note that mentions the World Bank as Secretariat and trustee of the Center, as well as the constitution of six trust funds, one per MDB. China would contribute with a total of 100 million US dollars for the financing of the Center, which would act in three areas: (i) capacity building, (ii) project preparation; and (iii) exchange of information and good practices. The last meeting of the consultation group for the MCCDF was held in Beijing on 10 January 2019. For the first time, a bilateral donor joined the consultation meeting. UK's DFID participated and signaled its availability to be a potential donor of the facilities of the center.

With 138 countries participating on a voluntary basis and building bridges between the Chinese DDBs and all the major MDBs worldwide, including two institutions led by China itself, the coverage and size of the BRI has no precedent. It constitutes the corollary of the new financial institutionalism proposed by China.

\section{A comparison with the US-led financial institutionalism}

The new financial institutionalism proposed by China envisages complementing and rebalancing (not replacing) the current financial order that is controlled by the IMF, the World Bank Group and the regional development banks created in the 1960s and the EBRD in the 1990s.

We argue that China's BRI followed similar motivation and rationale to those observed in the US Marshall Plan (see Marshall Foundation, 2018, for further details about the Plan), for the following reasons. Both initiatives provide 
significant added geo-political weight. Both the BRI and the Marshall Plan occur as a macroeconomic response to a deficit in global demand, of overproduction, and of disinflation. Both initiatives emerge also as a change in nature of their foreign policy relations, from pure bilateral to pooled bilateral and ultimately multilateral. Both the Marshall Plan and the BRI are complemented by the creation of MDBs that leverage them: the IBRD (US-led), whose first loan ever, of 250 million US dollars, was granted to France, ${ }^{11}$ and the AIIB (Chinese-led), respectively. Both initiatives represent also a critical step forward to underpin the internationalization of their currencies. Both the BRI and the Marshall Plan make use of a given foreign policy that financially supports large infrastructure projects abroad (in a pure Keynesian fashion) not only to (i) internally serve as a significant stimulus to the development of domestic demand; but also to (ii) increase the Chinese commercial, cultural and political influence beyond frontiers, critically consolidating a move towards global hegemony (Mee, 1984, characterizes the Marshall Plan as a central contribution to the American world hegemony). Finally, both initiatives offer a sizable comparative advantage to their domestic firms. The Marshall Plan was fully tied to US goods and equipment, while, although the Chinese financing is not officially tied in the BRI, Hillman (2018) estimates, as mentioned in previous sections than, $89 \%$ of all contractors participating in Chinese-funded transportation projects overseas between 2006 and 2017 were Chinese firms.

Nonetheless, there are several important differences between the Marshall Plan and the BRI. First, their size. Despite the flexibility of BRI financial and geographical boundaries, estimates about BRI's size vary between the nearly 1 trillion US dollars committed by the Chinese in its first stage (Perlez \& Huang, 2017; Kohli, 2017; Hillman, 2018) and the 8 trillion US dollars estimated in total investment if the full pipeline of projects in BRI participant countries was to materialize (Wo-lap, 2016; Balding, 2017; Moser, 2017). In comparison, the Marshall Plan amounted to 13 billion US dollars (approximately 127 billion US dollars in current value as of August 2015 according to our estimates). Second, its coverage. The Marshall Plan was narrowly focused in its geographic coverage, limited to 16 western countries, while the BRI, despite, again, some vagueness in the definition of its geographical coverage, is more inclusive, allows for participation on a voluntary basis, and fully covers at least the Asia-Pacific Region, Middle East, Eastern Europe and Eastern Africa. Third, financing nature. While the Marshall Plan financed mostly grants (just 1.3 billion

11 Interestingly, complemented with non-financial commitments such as limiting public expenditure in France and removing members of the French government linked to communist associations and movements (Bird, 1992). 
out of the 13 billion US dollars were loans, according to Marshall Foundation, 2018), the BRI finances loans, both concessional and non-concessional, and equity. Fourth, eligibility. While the Marshall Plan financed first shipments of food, staples, fuel and machinery and later investment in industrial capacity, the BRI finances mainly infrastructure, so it has a more structuring impact in the economy. Finally, the Chinese government claims that the shared and mutual benefit principle of the BRI critically differentiates the initiative from the Marshall Plan (see Mitchell, 2018).

\section{Conclusion}

Chinese financial institutionalism represents an important centralized step by the Chinese government towards new models of cooperation based on access connectivity, especially in Eurasia and South Asia. These financial institutions are vectors of geopolitical presence, based on geo-economic considerations for the provision of regional and interregional financial options as an alternative to the Western financial institutionalism. They are not able to replace the current global financial institutions, but the massive influence, networks and operations of the AIIB and the BRI and their success so far may contribute to the expansion beyond their initial boundaries and objectives. These financial structures already represent a regional alternative to the established global financial organizations.

The progressive internationalization of the renminbi, especially in the regions of Eurasia and South Asia, with the contribution of the BRI (as pointed out by Chan, 2017), will contribute to de-dollarize bilateral and multilateral trade, which will reinforce the success of the Chinese quasi-global financial institutions. Along the same lines, the impetus provided by the BRI, the AIIB, and the NDB; the possible synergies with the Eurasian Development Bank; and the accession of India and Pakistan to Shanghai Cooperation Organization all anticipate a new dimension of regional financial institutionalism, capable of gaining global momentum and intensifying financial interdependence. Indeed, the BRI structures of pervasive connectivity creating a network of interdependent economic agents, the simplification of payment methods, the digitalization of the Silk Road, the easy access to bond and stock markets, the volume of loans provided by Chinese lead institutions, the security and stability of the domestic development banks, and the balancing of governing rules in global financial institutions, will enhance the internationalization of the renminbi.

The stated purpose of this article was to inquire into the extent the creation 
of a new financial institutionalism to support the BRI access-connectivity strategy follows the same pathway of the US-led financial institutionalism. We found that it does follow the same pathway to a large extent. The four types of financial institutionalism - the creation of quasi-global financial organizations; the boosting Chinese participation in existing global financial organizations; the engagement of financial conglomerates of national organizations (the domestic development banks); and the financial component of China's partnership strategy - are intertwined constituents of a financial institutionalism to advance Chinese BRI and vision on a global scale. Therefore, the centre of the global scale access-connectivity initiative is Asia and Eurasia. The land corridors extend trade connectivity to almost everywhere in Asia and Eurasia, and the maritime road and the non-material Silk Roads, such as the digital Silk Road (see The Economist, 2018), have a global reach. Exceptions aside, all the major European, Eurasian, South and West Asian, African and American economies are involved, and all are looking to establish a reliable network of financial institutions capable of providing financial security to boost large scale development. Apart from the US, Japan is the only major player that has not yet become directly involved in this financial institutionalism; and Japan's involvement is crucial for regional stability. But the Prime Minister Shinzo Abe did not shut the door. He said in 2017 that Japan "could be open to joining the China-led AIIB if questions surrounding its projects' environmental impacts and other issues are resolved" (see Reynolds et al., 2017). China is likely to continue to invest in these new quasi-global financial institutions, to promote its domestic development banks conglomerates, to develop bilateral partnerships, and to entice Japan at the expenses of US isolationism.

Enrique Martínez Galán received his $\mathrm{PhD}$ in economics from the University of Lisbon in 2018. He is currently member of the Board of Directors of the Asian Development Bank with previous professional experience in the Asian Infrastructure Investment Bank, European Investment Bank, the World Bank, European Commission and Portuguese Finance and Foreign Affairs Ministries. He is a researcher, lecturer, reviewer and author of several books and book chapters in development finance, international trade, foreign direct investment, and the Belt and Road Initiative. Galán has co-authored several recent scientific articles published in the following academic journals: The World Economy, Applied Econometrics and International Development, and Portuguese Economic Journal. His most recent book is titled A Contribution to Evaluate the Impact of Global Value Chains (University of Lisbon, 2018).

Francisco José Leandro received his $\mathrm{PhD}$ in political science and international relations from the Catholic University of Portugal in 2010. From 2016 to 2017 he took part in a postdoctoral research programme on state monopolies in China-One Belt, One Road studies. In 2014 and 2017, he was awarded the Institute of European Studies in Macau (IEEM) Academic 
Research Grant, which is a major component of the Asia-Europe Comparative Studies Research Project. From 2014 to 2018, he was the programme coordinator at the Institute of Social and Legal Studies, Faculty of Humanities at the University of Saint Joseph in Macau, China. He is currently an Associate Professor and Assistant Dean of the Institute for Research on Portuguese-Speaking Countries at the City University of Macau, China. His most recent book is titled Steps of Greatness: The Geopolitics of OBOR (University of Macau, 2018).

\section{References}

ADB (2004), ADF-IX Donor's Report: Development Effectiveness for Poverty Reduction, Metro Manila: Asian Development Bank. Retrieved from https://www. adb.org/sites/default/files/institutional-document/32435/files/adf-9-donor-report. pdf [accessed 18 Jan 2019]

ADB (2008), ADF-X Donor's Report: Towards an Asia and Pacific Region Free of Poverty, Metro Manila: Asian Development Bank. Retrieved from https://www. adb.org/sites/default/files/institutional-document/32433/files/adf-x-donors-report. pdf [accessed 18 Jan 2019]

ADB (2017), Meeting Asia's Infrastructure Needs, Metro Manila: Asian Development Bank. Retrieved from https://www.adb.org/sites/default/files/publication/227496/ special-report-infrastructure.pdf [accessed Jan 2019]

ADB (2018), Annual Report 2017, Metro Manila: Asian Development Bank.

AfDB (2011), Agreement Establishing the AfDB, 2011 Edition, Abidjan: African Development Bank. Retrieved from https:/www.afdb.org/fileadmin/uploads/afdb/ Documents/Legal-Documents/Agreement\%20Establishing\%20the \%20ADB\%20 final\%202011.pdf [accessed 18 Jan 2019]

AfDB (2014), 'AfDB announces US\$ 2 billion fund with China,' AfDB Press release, 22 May, Abidjan: African Development Bank. Retrieved from https://www.afdb. org/en/news-and-events/afdb-announces-us-2-billion-fund-with-china-13165/ [accessed 18 Jan 2019]

AfDB (2018), Annual Report 2017, Abidjan: African Development Bank.

AIIB (2015), AIIB Articles of Agreement, Beijing: Asian Infrastructure Investment Bank.

Retrieved from https://www.aiib.org/en/about-aiib/basic-documents/_download/ articles-of-agreement/basic_document_english-bank_articles_of_agreement.pdf. [accessed 18 Jan 2019]

AIIB (2017), 'AIIB supports renewable energy development in Egypt,' Beijing: Asian Infrastructure Investment Bank. Retrieved from https://www.aiib.org/en/newsevents/news/2017/20170905_001.html [accessed 18 Jan 2019]

AIIB (2018), 'Who we are,' Beijing: Asian Infrastructure Investment Bank. Retrieved from https://www.aiib.org/en/about-aiib/index.html [accessed 10 Aug 2018] 
AIIB (2019), 'AIIB membership,' Beijing: Asian Infrastructure Investment Bank. Retrieved from https://www.aiib.org/en/news-events/news/2017/20170905_001. html [accessed 19 Aug 2018]

Armijo, L. E. \& Katada, S. N. (2014), 'Theorizing the financial statecraft of emerging powers,' New Political Economy, vol. 20, no. 1, pp. 42-62.

https://doi.org/10.1080/13563467.2013.866082

Balding, C. (2017), 'Can China afford its Belt and Road?' Bloomberg, 16 May. Retrieved from https://www.bloomberg.com/view/articles/2017-05-17/can-china-afford-itsbelt-and-road [accessed 10 Aug 2018]

Bird, K. (1992), The Chairman: John J. McCloy, the Making of the American Establishment, New York: Simon and Schuster.

Chan, S. (2017), 'The Belt and Road Initiative: implications for China and East Asian economies,' The Copenhagen Journal of Asian Studies, vol. 35, no. 2. https://doi.org/10.22439/cjas.v35i2.5446

Chandran, N. (2018), 'A proposed US initiative to be a 'clear alternative' to Chinese investment in Asia,' $C N B C, 7$ September. Retrieved from https://www.cnbc. com/2018/09/07/us-proposal-aims-to-be-alternative-to-china-investment-in-asia. html [accessed 18 Jan 2019]

Chhibber, A. (2017), 'China's Belt and Road Initiative and India's options: Competitive cooperation,' Journal of Infrastructure, Policy and Development, vol. 1, no. 2, pp. 242-253. https://doi.org/10.24294/jipd.v1i2.83

China Banking Regulatory Commission (2016), 'The CBRC Encourages the Banking Sector to Support the Belt and Road Initiative, Beijing: CBRC. Retrieved from http://www.cbrc.gov.cn/EngdocView.do?docID=7625F9239CA944B682CB9D4 3B8ADD190 [accessed 10 Aug 2018]

Deloitte (2018), 'Embracing the BRI ecosystem in 2018: navigating pitfalls and seizing opportunities,' Deloitte Insights, February 12. Retrieved from https://www2. deloitte.com/insights/us/en/economy/asia-pacific/china-belt-and-road-initiative. html [accessed 18 Jan 2019]

Djankov, S.; Freund, C. \& Pham, C. S. (2006), 'Trading on time,' WB Policy Research Working Paper, no. 3909, Washington, DC: The World Bank. https://doi.org/10.1596/1813-9450-3909

Dyer, G. \& Anderlini, J. (2011), 'China's lending hits new heights,' Financial Times, 18 January. Retrieved from https://www.ft.com/content/488c60f4-2281-11e0b6a2-00144feab49a [accessed 18 Jan 2019]

Dyer, G. \& Parker, G. (2015), 'US attacks UK's 'constant accommodation' of China,' Financial Times, 13 March. Retrieved from https://www.ft.com/content/31c4880ac8d2-11e4-bc64-00144feab7de?siteedition=intl\#axzz3UGUkd6H5 [accessed 18 Jan 2019] 
EBRD (2018), Annual Report 2017, London: European Bank for Reconstruction and Development.

Economy, E. \& Oksenberg, M., eds. (1999), China Joins the World: Progress and Prospects, New York: Council on Foreign Relations Press.

EPSC (2015), 'The Asian Infrastructure Investment Bank: A new multilateral financial institution or a vehicle for China's geostrategic goals,' European Political Strategic Centre Strategic Notes, no. 1, 24 April. Retrieved from https://ec.europa.eu/epsc/ publications/strategic-notes/asian-infrastructure-investment-bank_en [accessed 18 Jan 2019]

European Union (2018), 'Connecting Europe and Asia: Council adopts conclusion,' Press release of the Council of the European Union, Brussels, 15.10.2018. Retrieved from https://www.consilium.europa.eu/en/press/press-releases/2018/10/15/ connecting-europe-and-asia-council-adopts-conclusions/ [accessed 18 Jan 2019]

Government of China (2019), 'Country Profiles,' Belt and Road Portal, State Council. Retrieved from https://eng.yidaiyilu.gov.cn/info/iList.jsp?cat_id=10076 [accessed 18 Jan 2019]

Government of Timor-Leste (2015), 'GoTL signed loan agreement with ExIm Bank of China to construct and upgrade Dili drainage system,' Ministry of Finance Press Release, December 18. Retrieved from https://www.mof.gov.tl/gotl-signed-loanagreement-with-exim-bank-of-china-to-construct-and-upgrade-dili-drainagesystem/?lang=en [accessed 18 Jan 2019]

He, B. (2019), 'The domestic politics of the Belt and Road Initiative and its implications,' Journal of Contemporary China, vol. 28, no. 116, pp. 180-195. https://doi.org/10.1080/10670564.2018.1511391.

Heath, T. R. (2016), 'China's evolving approach to economic diplomacy,' Asia Policy, vol. 22, no. 2, pp. 157-191. https://doi.org/10.1353/asp.2016.0020

Hillman, J. (2018). 'The Belt and Road Initiative: five years later,' Statement before the US-China Economic and Security Review Commission of the US Senate, 25 January, Washington, DC: The Centre for Strategic and International Studies. Retrieved from https://www.csis.org/analysis/chinas-belt-and-road-initiative-fiveyears-later-0 [accessed 18 Jan 2019]

IADB (2012), 'China to provide $\$ 2$ billion for Latin America and the Caribbean Cofinancing Fund,' Inter-American Development Bank Press release, 16 March. Retrieved from https://www.iadb.org/en/news/news-releases/2013-03-16/chinaco-financing-fund $\% 2$ C10375.html [accessed 18 Jan 2019]

IADB (2013), 'IDB, China Eximbank further advance in the creation of equity investment platform for Latin America and the Caribbean,' Inter-American Development Bank Press release, 19 March. Retrieved from https://www.iadb.org/en/news/ news-releases/2012-03-19/china-latin-america-equity-investment-fund\%2C9894. html [accessed 18 Jan 2019] 
IADB (2018), Annual Report 2017, Washington, DC: Inter-American Development Bank.

Ikenberry, G. J. \& Lim, D. (2017), China's Emerging Institutional Statecraft: The Asian Infrastructure Investment Bank and the Prospects for Counter-hegemony, Project on International Order and Strategy, Washington, DC: Brookings Institution.

IMF (2018), Annual Report 2018, Washington, DC: International Monetary Fund.

Kohli, H. (2017), 'Looking at China's Belt and Road Initiative from the Central Asian perspective,' Global Journal of Emerging Market Economies, vol. 9, nos. 1-3. https://doi.org/10.1177/0974910117747760

Laroche, J. (2017), The Brutalization of the World: From the Retreat of States to Decivilization, Cham: Springer. https://doi.org/10.1007/978-3-319-50793-4

Marshall Foundation (2018), 'History of the Marshall Plan,' Lexington, VA: George C. Marshall Foundation. Retrieved from https://www.marshallfoundation.org/ marshall/the-marshall-plan/history-marshall-plan/ [accessed 20 Dec 2018]

Martínez-Galán, E. (2019), 'The challenges and the opportunities of the Belt and Road Initiative for participating countries: the case of Timor-Leste,' in I. K. Peng; F. J. B. S. Leandro \& D. Afonso-Henriques (eds.) The Challenges, Development, and Promise of Timor-Leste, Macau: City University of Macau, pp. 135- 162.

Mee, C. L. (1984), The Marshall Plan: The Launching of the Pax Americana, New York: Simon and Schuster.

Ministry of Finance (2017), Memorandum of Understanding on Collaboration on Matters of Common Interest under the BRI, Ministry of Finance of the People's Republic of China, 14 May. Retrieved from the repository of the NDB at https://www.ndb. int/wp-content/uploads/2018/09/MOU-on-BRI-signed.pdf [accessed 20 Dec 2018]

Ministry of Foreign Affairs (2018), Partnership for Quality Infrastructure, Ministry of Foreign Affairs of Japan. Retrieved from https://www.mofa.go.jp/files/000117998. pdf [accessed 31 Dec 2018]

Mitchell, T. (2018), 'Beijing insists BRI is no Marshall Plan,' Financial Times, 26 September. Retrieved from https://www.ft.com/content/48f21df8-9c9b-11e888de-49c908b1f264 [accessed 31 Dec 2018]

Moser, J. (2017), 'China's bridge to nowhere,' Forbes, 7 September. Retrieved from: https://www.forbes.com/ sites/joelmoser/2017/09/07/chinas-bridge-tonowhere/ \#41f713951568 [accessed 31 Dec 2018]

Nadkarni, V. (2010), Strategic Partnerships in Asia: Balancing without Alliances, London: Routledge.

Packham, C. (2018), 'Australia launches \$1.5 billion Pacific fund to counter China's influence,'Reuters, 8 November. Retrieved from https://www.reuters.com/article/ australia-china-pacific/update-2-australia-launches-15-bln-pacific-fund-tocounter-chinas-influence-idUSL4N1XI777 [accessed 31 Dec 2018] 
Perlez, J. \& Huang, Y. (2017), 'Behind China's \$1 trillion plan to shake up the economic order,' New York Times, 13 May. Retrieved from https://www.nytimes. com/2017/05/13/business/china-railway-one-belt-one-road-1-trillion-plan.html [accessed 31 Dec 2018]

Reynolds, I.; Hirokawa, T. \& Nobuhiro, E. (2017), 'Japan could still join China Infrastructure Bank, Abe Ally says,' Bloomberg, 7 December. Retrieved from https:/www.bloomberg.com/news/articles/2017-12-06/japan-could-still-joinchina-infrastructure-bank-abe-ally-says [accessed 31 Dec 2018]

Ruta, M.; Mulabdic, A.; Murray, S.; Rocha, N. \& De Soyres, F. (2018), 'How much will the Belt and Road Initiative reduce trade costs?' Reuters, 16 October. Retrieved from http://blogs.worldbank.org/trade/how-much-will-belt-and-roadinitiative-reduce-trade-costs [accessed 31 Dec 2018]

Shen, S. \& Chan, W. (2018), 'A comparative study of the Belt and Road Initiative and the Marshall Plan,' Palgrave Communications, vol. 4, no. 32. https://doi. org/10.1057/s41599-018-0077-9

Silk Road Fund (2018), 'Overview.' Retrieved from http://www.silkroadfund.com.cn/ enweb/23775/23767/index.html [accessed 12 Dec 2018]

Sirimanna, B. (2011), 'Chinese project loans at high interest rates,' Sunday Times, 19 June. Retrieved from http://www.sundaytimes.lk/110619/BusinessTimes/bt01. html [accessed 12 Dec 2018]

Standard \& Poor's (2018), 'The world's 100 largest banks.' Retrieved from https:// platform.mi.spglobal.com/web/client?auth=inherit\#news/article?id=44027195\&c did=A-44027195-11060 [accessed 18 Jan 2019]

Statista (2018), 'Bank deposits in China from 2006 to 2016 (in trillion yuan),' Statista database. Retrieved from https://www.statista.com/statistics/278004/bankdeposits-in-china/ [19 Sep 2019]

Strüver, G. (2017), 'International alignment between interests and ideology: the case of China's partnership diplomacy,' Chinese Journal of International Politics, vol. 10, no. 1, pp. 31-65.

Swaine, M. (2015), 'Xi Jinping's address to the Central Conference on work relating to foreign affairs: assessing and advancing major power diplomacy with Chinese characteristics,' China Leadership Monitor, no. 46. Retrieved from http:// carnegieendowment.org/files/Michael_Swaine_CLM_46.pdf [accessed 20 Dec 2018]

SWIFT (2018), 'RMB internationalisation: where we are and what we can expect in 2018,' RMB Tracker Special Report, January. Retrieved from https://www.swift. com/resource/rmb-tracker-january-2018-special-report [accessed 20 Dec 2018]

The Economist (2018), 'China talks of building a digital Silk Road,' The Economist editorial, Print edition, 31 May. Retrieved from https:/www.economist.com/ china/2018/05/31/china-talks-of-building-a-digital-silk-road [accessed 20 Dec 2018] 
The World Bank (2003), 2003 Spring Meetings Development Committee Communique, 13 April. Retrieved from http://siteresources.worldbank.org/DEVCOMMINT/ Resources/April-2003-Communiques/April2003DCCommunique_E.pdf [accessed 20 Dec 2018]

The World Bank (2007), 'China Eximbank and World Bank come together to sign cooperation memo,' The World Bank Press release no. 2007/EAP/376, 21 May. Retrieved from http://www.worldbank.org/en/news/press-release/2007/05/21/ china-eximbank-world-bank-come-together-sign-cooperation-memo [accessed 20 Dec 2018]

The World Bank (2008), IDA: The Platform for Achieving Results at the Country Level,

Final Report, 28 February. Retrieved from http://ida.worldbank.org/sites/default/ files/pdfs/finalreportmarch2008.pdf [accessed 20 Dec 2018]

The World Bank (2010), World Bank Group Voice Reform: Enhancing Voice and Participation of Developing and Transition Countries in 2010 and Beyond, Development Committee, 19 April. Retrieved from http://siteresources.worldbank. org/DEVCOMMINT/Documentation/22553921/DC2010-006(E)Voice.pdf [accessed 20 Dec 2018]

The World Bank (2011), IDA: Delivering Development Results, 15 February. Retrieved from http://documents.worldbank.org/curated/en/180391468330881664/pdf/6057 50BR0IDA1R10312811110BOX358324B.pdf [accessed 20 Dec 2018]

The World Bank (2015), 'Countries ranked by per capita income,' The World Bank Operational Manual, Operational Policies, 3.10, Annex C, July. Retrieved from http://web.worldbank.org/WBSITE/EXTERNAL/PROJECTS/EXTPOLICIES/ EXTOPMANUAL/0,,contentMDK:22634969 menuPK:4564185 pagePK:6470 9096 piPK:64709108 theSitePK:502184,00.html [accessed 20 Dec 2018]

The World Bank (2017), World Development Indicators: GDP (current US dollars).

Retrieved from https://data.worldbank.org/indicator/NY.GDP.MKTP.CD [accessed 1 Jan 2018]

The World Bank (2018a), Annual Report 2018, Washington, DC: The World Bank.

The World Bank (2018b), A Report to Governors on Shareholding at the 2018 Spring Meetings. Retrieved from http://siteresources.worldbank.org/DEVCOMMINT/ Documentation/23776699/DC2018-0003_PShareholding420.pdf [accessed 20 Dec 2018]

The World Bank (2018c), 'Three opportunities and three risks of the Belt and Road Initiative,' The Trade Post, The World Bank Blog, April 5. Retrieved from http:// blogs.worldbank.org/trade/three-opportunities-and-three-risks-belt-and-roadinitiative [accessed 20 Dec 2018]

Trading Economics (2018), 'China Foreign Exchange Reserves,' Statista database. Retrieved from https://tradingeconomics.com/china/foreign-exchange-reserves [accessed 19 Sep 2018] 
Wo-Lap, W. (2016), 'Getting lost in 'One Belt, One Road',' Economic Journal Insight, 12 April. Retrieved from http://www.ejinsight.com/20160412-getting-lost-onebelt-one-road/ [accessed 20 Dec 2018]

Woolcock, S. \& Bayne, N. (2013), 'Economic diplomacy,' in A. F. Cooper, J. Heine \& R. Thakur (eds.) The Oxford Handbook of Modern Diplomacy, Oxford: Oxford University Press, pp. 385-401. https://doi.org/10.1093/oxfordhb/9780199588862.013.0022

Zhai, F. (2018), 'China's Belt and Road Initiative: a preliminary quantitative assessment,' Journal of Asian Economics, vol. 55, pp. 84-92. https://doi.org/10.1016/j.asieco.2017.12.006

Zhang, S. \& Miller, M. (2017), 'Behind China's Silk Road vision: cheap funds, heavy debt, growing risk,' Reuters, 15 May. Retrieved from https:/www.reuters.com/ article/us-china-silkroad-finance-idUSKCN18B0YS [accessed 20 Dec 2018] 